This is the author's final, peer-reviewed manuscript as accepted for publication. The publisher-formatted version may be available through the publisher's web site or your institution's library.

\title{
Violence in mind and body: Jünger's heart, Brecht's brain, and Döblin's hand
}

Derek Hillard

\section{How to cite this manuscript}

If you make reference to this version of the manuscript, use the following information:

Hillard, D. (2013). Violence in mind and body: Jünger's heart, Brecht's brain, and Döblin's hand. Retrieved from http://krex.ksu.edu

\section{Published Version Information}

Citation: Hillard, D. (2013). Violence in mind and body: Jünger's heart, Brecht's brain, and Döblin's hand. Modernism/modernity, 20(2), 327-348.

Copyright: @ 2013 The Johns Hopkins University Press

Digital Object Identifier (DOI): doi:10.1353/mod.2013.0052

Publisher's Link:

http://muse.jhu.edu/journals/modernism-modernity/v020/20.2.hillard.html

This item was retrieved from the K-State Research Exchange (K-REx), the institutional repository of Kansas State University. K-REx is available at http://krex.ksu.edu 
Derek Hillard

Violence in Mind and Body: Jünger's Heart, Brecht's Brain, and Döblin’s Hand

When we interrogate depictions of violence, we characteristically seek to uncover how violence is glorified, aestheticized, hence legitimized. ${ }^{1}$ Unsurprisingly, this focus suits an approach that is both predominantly hermeneutic and devoted to reading texts as historically and ideologically symptomatic, because scholarship traditionally treats violent depictions as positions in moral, ethical, or political discourses. ${ }^{2}$ Crucial to such investigations are often questions about perpetrators or victims. In this line of inquiry, a leading, if unasked, question is how would one analyze this depiction if it were reality. Emerging into view, then, is a paradoxical cohabitation of fascination for the spectacular with the insistence on a corresponding real. The question of legitimacy is informed by an imperative that would run something like this: react to violence as if it were always real, according to the maxim that your reaction would become universal.

Consider the extensive research on violence. We might expect critical appraisal to echo the famous juridical threshold for obscenity: we know it when we see it. Noting that this is not the case, the film scholar Marco Abel proffers a "Spinozist provocation," namely, "We do not even know what violent images are, let alone how they work.”3 To assume that the stakes in violence always concern the characters, acts, and reality as content might get in the way of a more probing consideration of this question. Showing similar prudence, interdisciplinary theorists point out the difficulties in discussing such "an extremely complex phenomenon involving major ambiguity between the destruction and the creation of order." ${ }^{4}$ Yet it is not merely a question of quiddity but of modus and 
locus: where is violence and how do we know it?

The established lines of inquiry alone are not sufficient to account for ways of looking at violence. A symptomatic approach assumes an efficient fixity of act, actors, and ideologically received representation, one supported by a reliance on the concealed real. A formalist investigation may intrigue not only because it eschews the ubiquitous causal outrage but also because it reminds "that fictional violence exists only by virtue of the imaginative shaping and transformations of an author's touch." ${ }^{55}$ Nevertheless, by focusing on intention and authorial imagination, the formalist view overlooks readers and the question of mind and body. A Deleuzian framework, such as that of Abel, yields insight into the possibilities of finitude, but does its dependence on the trope of deferral not seem obligatory $?^{6}$ To take investigations of violence to the next stage, do we not need to locate a role for the reader's imagination?

$* * * * *$

In a 2000 essay collection, Karl Heinz Bohrer noted that “we look predominately upon violence as literary and artistic content, but do not ask ourselves about the form.”7 Artists present violence because its formal expression accommodates the impulse for a style that "jolts" or "wounds" readers. ${ }^{8}$ In this approach we see not just a shift to the question of form, one developed in Hans Ulrich Gumbrecht's suggestive study of LouisFerdinand Céline, published in the same collection, in which the reader "feels himself ever more remorselessly hounded by this prose." ${ }^{9}$ We also see a renewed exploration of aesthetic experience and the autonomous status of the work.

Informed by cognitive cultural studies or "bioculturalism," critics from other camps have begun to examine more closely experience in the context of art. ${ }^{10}$ Cognitive 
literary studies track in various ways. Much of this research studies what texts can reveal about mental states as represented in the work; other research looks for what texts can reveal about how our minds represent. Some descriptions of narrative in these fields argue that the same underlying processes are involved whether listening to a real person or to a narrator, in which the element of fictionality is downplayed, undertheorized, or dropped altogether. ${ }^{11}$ In the words of Monika Fludernik, "Readers construct meanings and impose frames on their interpretations of texts just as people have to interpret reallife experience in terms of available schemata." ${ }^{12}$ It is often assumed that readers regard the narrator as if she were a real person, in which the story is an encounter, as it were, with a real voice.

The notion that narratives are products not of authors but readers is a theory often associated with Roland Barthes. Presaged by early German Romantic theory and Nietzsche, this notion is also present, I argue, in works of German modernists such as Alfred Döblin. Due to the rich history of reader-oriented theory, cognitive readings make new claims not by referring to the "making something a narrative by the sheer act of imposing narrativity on it, [which] needs to be located in the dynamic reading process,”13 but by basing this process in natural schemas and cognitive frames, such as action, narrativity, or experience. ${ }^{14}$

Despite the arguments made for natural schemata, the theories do have a weakness. Such schemata are not directly experienced, only their surface manifestations in linguistic references or embodied indexes. If everything can be traced to a natural but unseen basis, then differences cannot emerge on this natural level. Distinctions only emerge when we examine the phenomena accessible to perception, phenomena that may 
or may not be natural. Available schemata, universals, frames and so on are imagined as untainted by the constructivist forces at work in imagination, science, and myth (power), so that constructivism is acknowledged on the basis of the schemata but not for the schemata themselves, which are conceived as unconstructed. At the same time, the concept of fictionality is at times abandoned without sufficient consideration, while the difference between spoken and written speech is often downplayed.

Though reading has reemerged as an area of significant interest, literary critics have not yet studied violence or its ties to emotion in the context of readers. ${ }^{15}$ To do this, we will need to ask what the relationship of body and consciousness is to violence in the context of the aesthetic. Such an investigation would not have an etiological, symptomatic, or juridical focus, but emphasize instead where and how narrative violence occurs and speculate about what particular, case-based reader reactions could be. This approach shifts the focus from the work as an autonomous entity with a ready-made profile of violence to one animated by the reader's consciousness and perhaps registered by the body.

Thus my first hypothesis is that the investigation of violence in literature is at its most insightful and accounts for indispensable elements when it sees how particular violence conjoins with the ways in which it is aesthetically experienced. Without the perceiving mind, violence in the work could not be fashioned. In this essay, the goal is not to examine a model of images (whether treated as real events or not) that have been fixed in autonomous fashion but to explore a dynamics of violence that is implicated in the experience of reading. ${ }^{16}$ As I will discuss, the subject is at once violence and at the 
same time the reader, who emerges as the one who does violence and the one to whom it is done.

Accordingly, this essay investigates three different models of reader reception of violence in works of three writers of the Weimar Republic era: Ernst Jünger’s early works, particularly Wäldchen 125 (Copse 125), Bertolt Brecht’s Die Maßnahmen (The Measures Taken), and Alfred Döblin’s Berlin Alexanderplatz. To get at the ways in which minds and bodies experience violence in writing, I would like to investigate both bodily metaphors and also the purported use-value of violence. ${ }^{17}$ This intention relates to my second hypothesis: Weimar Republic aesthetics were profoundly drawn to the question of violence’s possible use-value.

The three works in question, as my final thesis has it, conceive of at once different models of violence and at the same time different models of reader reception. The first model assumes a human continuum with nature, which results in a bodily identification with violence depicted as naturally autonomous (Jünger). Against this, the second model strives to make readers into sites of calculation, so that violence both depicted and real can be changed-yet its efforts result in a mixture of constructivism and identification (Brecht). By contrast, the third model assumes violence is embedded in the reader, which emphasizes how the reader's perception is reintroduced into the object of reading as violence (Döblin). Common to each is a reliance on bodily metaphors-respectively, heart, head, and hand-which frame the bodily appeal to the reader's situation. This essay, then, differs from most approaches to violence by analyzing body and instrumentality to get at the reader's role in the construction of violence. 


\section{The Heart: Jünger's Wäldchen 125}

In Ernst Jünger’s war narrative Wäldchen 125 (1925), a diary of trench warfare in 1918 France, violence is instrumentalized through the figure of sacrifice as a means to achieve sacral selfhood in the framework of nation. At the same time, the narrator contends that instrumental, economic, and utilitarian considerations of sacrifice offer a proof that the self who enters into this economy achieves sacral authenticity. In this way, the economic dimension props up a self that can be asserted only through its willingness to surrender to violence. Self-generation requires a sacrifice in the service of a sacral national mission.

Before coming to the issue of the reader in Wäldchen 125, violence must first be considered. Much can be said about the economy of violence at stake in this narrative: it is not merely one figure among many but the one that occupies the human core. ${ }^{18}$ For the narrator, the new European man of World War I was born on the battlefield, and the man of the future will also need to be made there. The will to sacrifice is the decisive factor in the construction of the new man, a man whose death and birth are conceived as one event. In a phrase that is telling for his entire output of this period, Jünger wrote how sacrifice connects death’s past and future to its present: “There, where such blood has flowed, is where an inheritance is assumed and beginnings are to be seen. Whether the

war is won or lost: that has not happened in vain.”19 At the same time, in Jünger's works, one key area of tension is that between violence perceived in aesthetic, that is, subjective—-versus collective and political—-terms, a concern that bears on the role of consciousness in the construction of violence. 
Regarding this violence: on the one hand, the pre-1935 editions of Jünger’s text refer to the goal necessary for the new self to emerge in violent sacrifice- " "the formation of all Germans in the future Reich of millions, for which it is worth dying and breaking all opposition." ${ }^{20}$ Jünger asks, "If young men have no great aim then why should they sacrifice themselves?”21 The source for this will may come from society, for instance, from education, public displays of memory, art, family, or philosophy. However, despite their powerful intentions, none of these social sources can generate an authentic will to fight and die, because this will, resting on sacrifice for its imagination, is religious: "The outer symbol that draws it forth is sacrifice."22

On the other hand, this particular employment of violence does not saturate its meaning. Particularly in his later writings and editions of the 1930s, Jünger tried to empty the myth of a goal or content, a gesture that has been neglected in much of the scholarship. ${ }^{23}$ While the instrumentality of violence is strongest in the early texts under consideration here, they too reveal a direction the later texts would take. In this connection, one sees how in works such as Wäldchen 125, "Der Kampf als inneres Erlebnis” (Battle as an inner experience) (1922), and Feur und Blut (Fire and Blood) (1925), the fight itself supplies a primordial timelessness, whereas the particular motivation for violence is contingent. For instance, in Feur und Blut, battle "occurs not for us, not for our nation, not for the group of nations allied with us. It occurs for the earth itself. ${ }^{24}$ Most telling in this respect is the description of value and determination by the narrative voices of Wäldchen, Feuer, and "Kampf als inneres Erlebnis." The justification is not a matter of morality but one of the battlefield ethos of agon. One kills in battle not those for whom one has no respect, not those who are not worthy of life, but 
on the contrary, the most respected. ${ }^{25}$ What emerges in the place of the noble cause and the division of combatants into manifestations of good and evil is the value placed on becoming hallowed through the fight.

To an extent this tension is reconciled: while Jünger’s construction of violence involves a central ecstatic experience, this experience is put to use time and again via the symbol of sacrifice in the cause of nation or the production of authenticity. At the same time, Jünger’s ecstatic battlefield sacrifice is not a mimetic representation of nature or death, one that would then find an aesthetically mediated presentation for a reader or listener, a matter to which I will return presently.

Why violence occurs is a significant question for the consciousness of readers. For this is also to ask what role the observing consciousness has other than the imposition of a narrative frame. Jünger's works are replete with references to war and violence as natural. For instance, in "Kampf," the narrator writes that "War is no more a human institution than the sex drive; it is natural law. ${ }^{26}$ Similarly, in Blätter und Steine (Leaves and Stones), Jünger writes, “[J]ust as war is not a part of life, but the expression of life in its full violence, so this life is in itself fundamentally warlike.,27 Battlefield situations allow humans to be the agents of the greatest and most heroic acts. ${ }^{28}$ Yet war is at all times clearly part of human consciousness and the body. The narrow field of action for humans is encapsulated in the ability to bring their own will into accord with nature through "sacrifice, whose basis is the highest freedom." ${ }^{29}$ In doing so, they become something more than mere nature: "Everywhere in this war we are brought into contact with the miraculous; we sense driving powers beyond consciousness, a mighty will, to which we are apt to surrender ourselves. ${ }^{30}$ In the struggle for survival and the assertion 
of culture, the choice to fight is a tactical advantage. Violence will erupt, and those who choose to join battle and choose wisely can live beautifully and intensely and perhaps enable a culture to thrive. We cannot change or overcome the natural law of violence; but we can master our relationship to it, just as we can master our relationship to pain. ${ }^{31}$ The manner in which subjects will face violence is essentially the only area of action remaining open. Why is violence exercised? For Jünger, it is an innate human drive, one located in a vague continuum of mind, body, and cosmos - the only route to self and spirit.

Thomas Weitin has shown how in the effort to present war as natural-the early writings position themselves as a direct registration of war-Wäldchen 125 aims to efface the medium of the literary text by claiming its earliest battlefield notations are impressions of natural events. ${ }^{32}$ Yet I not only wish to stress how nothing is left for the witness but to observe the "wavy line of a Seismograph” that tracks combat, but even more so, to mark a corresponding gap for the reader in Jünger, one that scholarship has not yet touched. ${ }^{33}$

I wish to discuss this by examining a well-known scene in Feuer und Blut, which Jünger rewrote in successive publications. ${ }^{34}$ Critics have persuasively argued for the centrality of allegory and sight in Jünger's oeuvre. ${ }^{35}$ Yet in stressing the role of the heart in this oft-reworked passage, I wish to point out how it becomes a trope for deflecting the visual and a means for imagining reader impact. Constructed as an imitating recipient of real violence, the narrator serves as a model for the imagined reader. The episode concerns an explosion that lands in a trench, wounding and killing a dozen soldiers, leaving a "throng of bodies that writhes like an amphibian in a boiling lake." ${ }^{36}$ Neither 
the sound nor sight of the blast but the way in which vision is transferred to other bodily systems freezes the narrator's body: "Your heart wants to turn this image away, yet, in all its horror, takes it in.” The image of ruined bodies is quickly routed over the mind straight to the heart, which asserts an interdependence of sight and inner organs. Although the narrator wishes to stress the power and primacy of the visual, impulses of the body take command, at first by trying to resist and finally by taking over the work of the eyes.

Because the wounded bodies are placed into intolerable states and spacesanimals in an undifferentiated and agitated liquid state- they immobilize the participant. He recognizes them (as human bodies) in their unrecognizability (as mass of inhuman stirrings). Indeed, the soldiers' destroyed bodies cannot be captured in an image because their effect is not limited to the visual. Having become first imprinted in the narrator's brain, they are then translated into a body experience localized in the heart. This heart is not a metaphor merely for emotions but also for the body as contractile, muscled force to which the cognitive-visual has yielded. Having supplanted the eye, the heart wants to shut itself off, but it cannot—something from the outside has manifested itself within in the form of passive stasis.

What interests me here is not how the author or narrative voice fortifies itself against purportedly real traumatic war-effects, but how Jünger’s texts imagine a “fortified” reader. The reader should construct a world of natural violence in which he, like the narrator, is placed. By shifting the mode of reception from visual to cardiomuscular, the text aims to register a bodily impact, with the heart behaving like a chamber that will contain acts of presentation. ${ }^{37}$ Unable to repel identification with 
suffering, the body surrenders to the heart's passivity. The text becomes a cardiograph for nature.

This scene also acknowledges how the narrator-reader is an inextricable part of the violence, not as its construer, and not because he fails to intervene, but as part of natural phenomena due to his role as mirror of violence. The affected body in the scene does not offer a significant position for the reader, only a passive reception. If we are to adopt the narrator's perspective, we are repulsed with him at what he feels, but the only act is flight or fright. Though demanding a response, the narrative blocks it through the observer's muted gesture. In the final step, the scene is recuperated to a natural event. Mirroring the naturality of procedures and their representation, Jünger’s narrators of the interwar era envision no significant active role for the consciousness that apprehends the text. In works such as Wäldchen 125, Feuer und Blut, or "Der Kampf als inneres Erlebnis," the violence depicted is not regarded as dependent on readers or the "narratee." This objective element to violence rests not on the chronicalistic status of the works but on the notion of readerly consciousness informing them. ${ }^{38}$ Soliciting recognition, the narrator in Wäldchen 125 presents events that are totally coherent and fashioned as if they were cut from reality. As such, they purport to be the direct manifestations of deeply rooted natural phenomena. As a result, the narrator envisions a reader who views the story as an event that is at once strange, experienced by another, and at the same time familiar, natural, and objective. The reader is not asked to narrate the other but to recognize the self in the other. For instance, in a section near the narrative's climax, the raging battle for the fighters in the copse becomes a "cosmic event [...] before which the people [...] play a minor and meaningless role.”39 
This can be appreciated when we recall that nature and mysticism make good bedfellows. Because violence conceived as nature relies not on human actors for its being but on passive observers, the socio-political dimensions can be ignored to the benefit of religious ones, which are as impersonal as nature. As a result, cosmic violence enables the production of an authentic self through the subordination of the will. Once produced, this self can justify itself through the aesthetic or be put to use in the service of the nation.

The role of the fighter mirrors that of the reader in Jünger: the reader is to adopt the protagonists' sense of wonder at the manifestation of natural violence. Accordingly, everything is mobilized so as to situate the reader geographically in violence as a surrounding natural landscape. How readers will actually respond to the narrator's efforts at emplacement is an open question. The reader may adapt the stance of the protagonists, wondering at the sublime natural rhythms of violence, or turn from them as literary fantasy. In any case, the reader's intended role is to inhabit the cartography of destruction without imagining that narrator and violence are reader-dependent for their being. Invited to recognize itself as a transeunt part of an inter-subjective mind, the mind knows violence before it externally encounters it. Indeed, the reading mind appears as a pullulating element of violence in its cosmic expression, a part that recognizes itself in the purported other of nature. In a twist reminiscent of Hegel's treatment of spirit, violent nature appears as an infinite self-reflecting subject, one that becomes manifest through its particularization in the minds of finite creatures. ${ }^{40}$

\section{Athletes of the Mind: Brecht's Die Maßnahmen}


For Jünger, violence depends on the passivity of readers. Characters are of concern only with regard to attitudes toward violence, not to its event. As a result, the narrative voice frequently presents violence as framed by or bound up in a choice, in which it is the chief field for attaining selfhood. Because violence is key to selfhood, it can be economized and instrumentalized for such purposes as nation.

Literary historians typically place Jünger in the camp opposite Brecht, ${ }^{41}$ who does not share with Jünger the view that violence is at once natural and at the same time a means of authentic self-presentation. Yet just as violence in Wäldchen 125 or Feuer und Blut is not without an instrumentalization, which is central in Brecht, its presence in Die Maßnahmen (1930/1931) is not without a concern with the self, a feature shared with Jünger. In Die Maßnahmen, this self is only fully actualized in the moment that it can merge with the community by being willingly killed. David Pan has recently stressed sacrifice as public phenomenon in Brecht's work. ${ }^{42}$ According to this view, death becomes a profound public act, allowing the production of a social self in death denied in life, where ego-centrism prevents the unfolding of a developed self. Hinting at this notion, the control chorus stresses at the play's conclusion how social change can occur only through the "comprehension of the individual and the whole." ${ }^{43}$ Centered in the death of the Young Comrade, the paradoxical interdependency of self and community points to a commonality with the early Jünger, a commonality resting on the shared view of violence in economic terms.

If Die Maßnahmen belongs, as Brecht stated, to those "suppleness-exercises” (Geschmeidigkeitsübungen) so that "athletes of the mind" (Geistes-Athleten) become "good dialecticians," 44 then practice relevant to violence is the core embodied mental 
maneuver. The preparations for this mental exercise are laid in the opening of the play, in which the killing of the Young Comrade is reported: “The Control Chorus: Who killed him? / The Four Agitators: We killed him. We shot him and cast him into a lime-pit.”45 The remainder of the play narrates the possibilities of response for the performer/viewer. In the logic of the Lehrstücke (learning plays), the viewer should take the perspective of the chorus, whose judgment (Urteil) is sought about the acts of the Four Agitators and the Young Comrade. ${ }^{46}$ The viewer's role is to judge judgments.

Indeed, Die Maßnahmen amounts to a sort of training in the cognitive processing of violence. One member of a band of revolutionaries agitating in China, the Young Comrade, repeatedly errs and jeopardizes the mission by displaying sympathy and impulsive emotional expression instead of cold calculation. As a result, after convincing the Young Comrade of the appropriateness of the act, his comrades kill him so as to preserve the body politic and keep the cause alive. For the political body of the revolutionary movement to live, it must be prepared to sever a limb, in which life must be destroyed for the future community: “And so we decided: we now / Had to cut off a member of our own body / It is a terrible thing to kill." ${ }^{47}$ Players and viewers — with his Lehrstücke Brecht famously aimed to eliminate the barrier separating these stancesweigh actions to learn the economy of violence.

In the view of Die Maßnahmen, we need to accept violence at present so that there might be an end to it: "For violence is the only means whereby this deadly / World may be changed." 48 Rather than accepting this, the Young Comrade rejects the economies of destruction and is undone by the contradiction of individual and collective. As a result, he becomes the sacrifice; for sacrificed are not only the current victims and their 
situations but also the ability to act based on feeling and the here and now, which explicitly characterizes him. While critics dutifully stress the didacticism of such scenes, the comrade's death nevertheless has the effect of a calculated exchange whose aim is to efface the distinction of aggressor and victim. The other agitators mention three times that they will first shoot the Young Comrade and throw him into the burning lime pit (Kalkgrube). Once lying there, covered with limestone, he recalls a ritual immolation and sacrifice:

Then we shot him and

Cast him down into the lime-pit

And when the lime had swallowed him up

We turned back to our work. ${ }^{49}$

Recalling how Kalk forms the etymology of the word calculation, we see how this "work" drives home the concern with instrumentality.

Jünger's narratives of violence aim to restrict readers’ representational

movement—boxing them in, so to speak, so as to preserve a traditional focus on heroism and nature, which aims to use the body for nature-empathy and shock. By contrast, in Die Maßnahmen, the control chorus asks its viewers/readers (and performers) to contemplate turning sacrifice into a site of calculation: can the rite be used as a tool of political violence to overturn its necessity?

The exercises in violence-cognition are not just represented in the play; they are also to be completed in the consciousness of the viewer/reader. Die Maßnahmen is a frame-story in the form of a dialogue structured as an inquiry. The narrator could be said to be the Control Chorus that interrogates and receives the story of the participants within 
the frame narrative. Die Maßnahmen aimed to accomplish a transformation of viewer/actor from one who, like the Young Comrade, behaves emotionally and opposes sacrifice to one who gains practice in sacrificial thinking and action, that is, one who can weigh gains against losses and decide accordingly. By jettisoning those limbs (severing “one’s own foot from the body”) susceptible to contradictory and paradoxical actions, one hopes to preserve the body politic, and the greater aim of social revolution comes closer to realization through this economic act.

Yet the prominence of the analytic betrays an underestimation of embodied imagination in viewership. ${ }^{50}$ How viewers responded to Brecht's Maßnahmen has been documented: they reacted emotionally to the fate of the Young Comrade. While Brecht famously envisioned critical responses emphasizing understanding and meaning, responses that eschewed identification and empathy, Antony Tatlow shows how viewers of the play from the 1930s to the 1960s frustrated this expectation..$^{51}$ That the play cues viewers to empathize — at once with the Chorus in its role as judge and at the same time with the Young Comrade in his role as sacrifice—can be seen in the words of the Chorus as the Four Agitators report their killing of the Young Comrade: "We sympathize [Mitgefühl] with you. / It was not easy to do what was right." ${ }^{, 52}$ Why this shift from reasoned judgment to emotion? ${ }^{53}$ Does killing lie on the far side of judgment where affect prevails? Brecht's locating sympathy in the Chorus with the Four Agitators as the empathetic object was designed to draw empathy away from the Young Comrade. Yet this very structure of sympathizing with the sympathizer instead allows the performer/viewer to sympathize with the Young Comrade, an event that squarely locates 
violence in viewing: in the act of sympathizing with viewers, the secondary viewer (or performer) carries the violence in her mind and body.

That the text asks the performer to empathize with the killers is less significant than its inability to draw away viewers' identification with the killed. Finding the violence malevolent, capricious, and repugnant, viewers and performers rejected it, and in doing so reproduced the affective stance of the Young Comrade. Their reaction betrays a resemblance to the ancient understanding of tragedy, which derives not mainly from interpretation but impact. Despite Brecht's repudiation of Aristotelian focus on emotion, and in the face of critics' fealty toward the Brechtian program, above the play hangs an air of the tragic.

In this regard, Brecht's experimental aesthetic of the Lehrstück anticipates concerns of cognitive reader-centered aesthetics by decades. Brecht too regards the work as a pragmatic progressive construction instead of as an autonomous inalterable work. Yet Brecht located constructivism in the work itself, in formal externality, by which I mean in an altered iteration of the play as a result of a critical intervention. ${ }^{54}$ This was envisioned as a reaction to dynamic social processes, not to invariant biological features. Brecht did not foresee that the viewer might react by constructing an internal image of the body marked by violence on the stage. Yet it may be the case that this viewer will represent, as it were, for her mind an "emotional body state," one that simulates the violent body on the stage as if it were her own. ${ }^{55}$ If this is the case, then Brecht's repeated efforts at altering the play in reaction to the viewers so as to block certain kinds of emotion were complicated due not to the work but to the body. 


\section{Döblin's Berlin Alexanderplatz}

As we saw, Jünger's Wäldchen 125 constructs text as copse where shell-shocked acquiescence is the only impact. By contrast, Brecht's play aims at once to portray a complex social reality and at the same time to appeal to analytical faculties. While Jünger’s Wäldchen does not engage with the notion of the animating reading consciousness at all, Brecht's Maßnahmen offers a violent formality for the mind to reconstruct. Yet the real status of the represented images of violence is never in question, as the violence is assumed to exist recognizably outside consciousness.

In this context, Döblin’s Berlin Alexanderplatz (1929) is unique for figuring violence as perception and impact, which is also to say, for collapsing the distinction between the narrated and narratee. The notion that violence has a symbolic character is a commonplace. ${ }^{56}$ Unique is that Berlin Alexanderplatz extends violence to include the perceivers' acts of shattering and reorganizing the material it perceives. The novel carries this insight into its bursting linguistic plenitude. Violence thus operates in conversation, advertising, song, politics, religion, myth, and economy in such a way that it experiences transference from languages about violence to an efficacious progressive perception as violence. In this account, violence is not restricted to representations of powerful destruction. Instead, we perceive violence because it is an ineluctably distinguishing act that (cognitively and bodily) creatively destroys. Berlin Alexanderplatz anticipates Abel's comment that it is not yet known "what violent images are and how they work." Yet instead of proposing an account of violence on par with a Deleuzian deferral, Döblin’s novel regards violence as a bracing and efficacious perceptual impact. Berlin Alexanderplatz does not just move the reader but does so by making her feel as if she is 
the agent of destruction. The domain of presentation in the novel joins with a reading that must bring vast, active resources—sight, touch, and sound — to bear so as to perceive and sense the evermore-extending space of fractures and at the same time to violently wrest an ordered space from the fractured.

Critics have seen violence in Berlin Alexanderplatz in terms of a productive sacrifice or trauma, and as primarily directed against women.${ }^{57}$ For other critics, both the city and the body of the protagonist Franz Biberkopf emerge as indexes of urban and social violence. ${ }^{58}$ Each of these approaches stresses not only representational content but also character agency. Let us take the discussion to the next stage by examining what role the consciousness and affect of the reader plays in the production of violence, and how the novel reflects on this.

Agency is commonly understood to be a fundamental component in the consideration of violence, which is thus conceived in terms of collective or individual/private. ${ }^{59}$ In Berlin Alexanderplatz, agency is not a central concern. While the segments with Biberfkopf and his psychotic friend Reinhold as "wounders” of bodies form a dense narrative strand, they occupy only a small quantity of Berlin Alexanderplatz as a text. Likewise, collective violence, while often hauntingly evoked in martial ciphers and images of battlefield carnage, remains marginal. Indeed, for all the fascination with Berlin Alexanderplatz's individual acts of violence and their colorful perpetrators, its main concern is not with subjects who do violence to each other-regardless of whether subjects are conceived as freely capable of making decisions or controlled by urges and emotions. 
Instead, the dominant violence is one of impact and communication. One can also consider it in terms both anonymous and autonomous. ${ }^{60}$ Anonymity can, as Bernhard Waldenfels argues, be conceived in terms of the embodiment in a body that is never entirely our own. ${ }^{61}$ But this does not account for the materiality and linguistic nature of violence. For that, we also need an embodied mind that actively participates in the novel's discourse. Emphasized is aggression not accountable in terms of causality and explanation but in terms of discourses, media, reading, and technology, as well as a kind of violence that a reader finds adhering in the formal dimensions of narrative, a matter I will come to shortly.

As we have seen, despite their differences, both Brecht’s Maßnahmen and Jünger’s period texts see violence in a useful economy—Jünger with regards to the aggrandizement of the authentic self, Brecht with regards to goals of community and social progress. ${ }^{62}$ Violence as waste in Berlin Alexanderplatz is in stark contrast to its role in Die Maßnahmen and Jünger’s works from the around the same time. This is in part due to narratological assumptions. In narrative terms, neither the characters nor their acts of violence in Berlin Alexanderplatz move the action forward as they do in Brecht or in classic city novels. Instead of emphasizing character intentionality, Berlin Alexanderplatz places great weight on the constructed city, the reader, and the book as terrains of signs.

Examples of violence as uselessness are numerous in Berlin Alexanderplatz: the beatings and deaths of Mieze and Ida, the great changes to old Berlin, citations from Greek tragedy and the Bible, the slaughterhouse scene, the loss of Franz's arm, which is at the core of the "violent cure" announced by the narrator. ${ }^{63}$ The most compelling plot- 
based evidence in the case for violence as waste, which can also be called the aesthetic, is Biberkopf's death, a death that tenaciously refuses agendas of empathy, tragedy, or Bildung. Violence is never involved in a successful instrumentalization, not even for the generation of a self. The novel shares concerns of autonomy and sovereignty with the works of Jünger and Brecht yet displays significant differences: for there violence is instrumentalized for the production of a robust "metalicized body." 64 This is to say that Berlin Alexanderplatz takes a much more nuanced and deliberately complicating approach to its concern with sovereignty of the self over and against violence in the age of the machine, an approach implicated in Döblin's concept of epic literature. Violence in Döblin is neither efficient nor mobilized. Rather it is open to chance; contradictory, it is capricious, luxurious, and wasteful. Accordingly, Berlin Alexanderplatz feints with the Bildungsroman, a tale of a modern man who progresses from willful pride to humanistic autonomy with a place in the community, only to push the reader outside the ring of the productive. The novel's narrative of enlightenment through the renunciation of myth and violence is structured by a contradiction. It purports to depict the maintenance of an enlightened self, yet this self must rely on violence to overcome the power of mythic violence.

The ends of both narrative and protagonist get at the question of use-value and violence. In particular, the novel's logic suggests that the instances of cool, calculating, and often violent exchange, to which Maria Tatar skillfully draws our attention, ${ }^{65}$ is overcome with the conscious surrendering of the self. Indeed, with staggering variety, the motif of giving, giving away, exchanging, and sacrificing, characterizes the actions of Döblin’s figures. Clytemnestra, in whose life the central event is sacrifice, appears via 
paraphrases of Greek tragedy; the recitations of Abraham's sacrifice of Isaac, are vivid, and the male figures—Franz, Reinhold, Herbert, Lüders—repeatedly engage in various kinds of gift-giving. Foremost in the sacrificed body is Biberkopf's arm, one rich in significance. ${ }^{66}$ Certainly Döblin considered self-surrender to be part of sentient beings' natural condition, as he wrote in Das Ich über der Natur (The I Above Nature): "Givingaway rests within ourselves; we age, die. ${ }^{, 67}$ The nobility of violent sacrifice, mobilized from the tragic language of the Bible and Greek antiquity, would seem to be an attempt to dignify, overcome, even short-circuit the brutal exchange principle at work in the text. Confronted with death, Biberkopf is ready to yield himself, to remove himself from the chain of exchanges and enter into the true gift: "He who lies here and offers up his life and his body is Franz Biberkopf." ${ }^{68}$ Yet cool exchange and the surrender of the self or of body parts do not lead to a greater good, as does Brecht's severing of the limb, but merely to more force.

Many scenes reveal the novel as a travesty of the Bildungsroman. For instance, in its fragmenting, breaking, chopping, and immolation the self mimes an initiation, a rebirth as a mature subject: "Now we must describe what pain does to Franz Biberkopf. Franz does not resist, he surrenders and gives himself up as pain's victim. He lies down in the blazing flame in order that he may be slain, destroyed, and burnt to ashes." ${ }^{69}$ This passage reads like a parodic condensation of rites of passage familiar from ethnographers such as Arnold van Gennup, where novitiate are removed to the forest—-here, the insane asylum, Buch ${ }^{70}$ —and, in the words of van Gennup, "subjected to seclusion, lustration, flagellation, and intoxication" followed by "transition rites, including bodily mutilations (circumcision)." Finally, "Since the novices are considered dead during their trial period, 
they go about naked”-_They speak a special language and eat special food." ${ }^{\text {,11 }} \mathrm{A}$ comparison with such ethnological accounts emerges: "Without a stitch on," force fed "milk and eggs and bit of cognac,"72 Biberkopf spoke "a few words, opened his mouth, sighed or groaned, although nobody was able to make anything of these sounds." ${ }^{\text {73 }}$ Though a powerful urge to perceive the narrative along natural or developmental lines may be in play for readers, the goal of a fully developed self is abandoned for the sake of an unstoppable pendulum of creation and destruction.

While bodies in Berlin Alexanderplatz register violence in striking ways, violence is less done by Döblin's figures than it is embodied in them. So Reinhold, who, like all the characters of Berlin, finally, "is through playing his role," as the epic narrator playfully remarks at the book's conclusion, appears as "cold force” (Gewalt), an allegory of violence. ${ }^{74}$ Indeed, Reinhold emerges as the cold brutal epiphenomenon of the posthumanist age as theorized in Döblin’s essay "Der Geist des naturalistischen Zeitalters” ("The Spirit of the Naturalistic Age”). Likewise, in his "Das Ich über der Natur," a work that he closely associated with Berlin Alexanderplatz, Döblin characterized the drive behind life as an anonymous animating force (Gewalt) ${ }^{75}$ In his efforts at conceiving of world and self without the subject-object dualism, violence for Döblin becomes the world manifesting itself for a body and mind to perceive it.

While anonymous violence has already formed the world for us, we can recast it, albeit not according to our will. Unlike Brecht, for whom analysis and institutional constraints are central, or Jünger, who stresses natural urges, Döblin emphasizes this recasting according to limitations due to bodily organs-including limbs and sense organs - which have been restructured from preexisting forms and together now construct 
a "Zertrümmerungsapparat” (fragmentation apparatus) ${ }^{76}$ Similarly, in “Der Geist des naturalistischen Zeitalters," he writes of "the other organ-systems and brain parts" that had atrophied in the metaphysical age and that are now activated in the materialistictechnical era — the "muscles, eyes, ears and their neuropsychical projections.",77 Previously decisive only in war, these organs have now generally transferred their martial training in the age of technology. Activated and extended by technology, the senses place the body and psyche in a state of constant conflict. At the same time, the city as body is a form of extended cognition: "The new spirit turns cities into its body."78 The agents of violence are conceived no longer as humanistic subjects of the metaphysical era but as bodies of destruction. Because this age witnesses the merging of city and book, Berlin Alexanderplatz materializes as a body for its violent and animating spirit, one that is recast in its fractures and fractures things so as to recast them.

\section{Arm and Hand}

Regarding this recast body, Walter Benjamin remarked that the overwhelmed reader of Berlin Alexanderplatz remembers two central (violent) events: Mieze's murder

and the loss of Biberkopf's arm. ${ }^{79}$ Indeed, the arm is implicated in the novel's key formal distinction, for Arm has the etymological meaning of to join, which is to say that the counterpoint at work in question is one of joining and breaking. ${ }^{80}$ This subsumes the visual concept of montage, which Benjamin saw as the novel's "stylistic principle.»81 Linking story, character, language, form, and terrain, violence as perception is more comprehensive than montage, for in its Döblinian sense, it is the unity of the difference of 
creation and destruction, a unity that marks all bodies, including the hand as both subject and object.

Consisting of cuts, fragments, and breaks, the lyric form of the novel embraces what I would like to call literary Fraktur. With this metaphor I wish to denote the particular ways in which meaning and form are merged in the novel. Etymologically, Fraktur, “a break,” derives from Latin fractura, “a breaking,” and frangere, “to break.,"82 Referring in the history of medicine to a broken bone, it is linked to the word "fragment" and "fracture," and also conveys destruction. As a kind of typesetting, it signified the angular and "broken” type of Gothic as opposed to the round type preferred in Latin style. Due to the distinction of Latin versus the German of the common people, it came further to signify plain, German-language speech. Fraktur thus can be used to collect several strands together in the novel: fragmentariness, the broken body (Franz's arm), the visual and tactile quality of print, directness, destruction, violence, trauma, and violation. Most significantly, Fraktur collapses the distinction between text and violence. Through reading the broken script, the reader becomes both agent and witness to the violence done to bodies and texts.

As a kind of cutting-machine, this Fraktur-book transforms its force, its Gewalt, through the course of the narrative, producing characters, meaning, and events, explaining for instance, why death's hands wield the cleaving axe against Franz's body. Indeed, as the narrator puts it: “It [the dark power, death] speaks Fraktur with him.”83 Death explains Franz's errors, that is, it speaks clearly, violently, and in Germanmeanings of Fraktur. Following the other meaning, this dark violence, “redet Fraktur,” speaks the broken script, which is to say in a chopped and chopping manner of 
signification and perception. This script of destruction routinely enunciates itself, often in the form of self-replicating language drills: "I beat everything to pieces, you beat everything to pieces, he beats everything to pieces. ${ }^{\text {84 }}$

Such linguistic transformations run parallel to the alterations to city space such as Alexanderplatz, the square about which Benjamin remarked in his review of the novel: "the site where for the last two years the most violent transformations have been taking place $[\ldots]$ where the innards of the metropolis $[\ldots]$ have been laid bare to a greater depth than anywhere else. ${ }^{, 85}$ Berlin Alexanderplatz is creating a new kind of literary Fraktur, one that intersects distinctions of narrative, religion, human relations, economy, politics, and space in the repetitive effects of pushing, breaking, and fracturing. Its aim is not to move the story but the reader.

Central to this metaphor of Fraktur is the metonymic suggestion of the hand and arm that both writes, signifies (pointing), destroys, and is destroyed. The loss of Biberkopf's arm, the tool of violence against Ida and Lena, results in an empty space, which suggests that the novel itself wishes to become a hand in its place. By considering the hand—Döblin's and that which a reader imagines in and behind the signs placed on the page — we can understand violence differently. ${ }^{86}$ Instead of conceiving of violent representations, we are asked to imagine a manual gesture embodied in the work. Here it is worthwhile to note not only the rhythmic interjections of the various texts in the novel but also Döblin’s compositional practice, which consisted of manually pasting cutout snippets of newspaper and other found texts directly onto the manuscript. I want to suggest that not only in the novel's thematic and formal dimensions, but also in the genetics of its material, we can see destructive and creative movements. In particular, in 
the fractured form of the novel, we glimpse the movements of the hand that writes the line, cuts out the newspaper notice and pastes it onto the manuscript, like the hand that has left a brushstroke on a canvas or the thumb that has molded clay into an image. Our tactile eyes become fingers tracing these gestures. In this way, Berlin Alexanderplatz is an exemplary handbook of violence.

The difference introduced by Berlin Alexanderplatz can be appreciated by considering episodes of impact from the novel, for instance the scene in the cinema with Herbert and Eva: "In the third act when the noble hero is apparently killed by a bandit, Eva sighs. And when Herbert looks her way, she's just about to slide off her seat, and she faints, imagine it." ${ }^{87}$ In Eva’s reaction, the wounded body she observes on the screen becomes part of her experience. Yet the novel's Fraktur unsettles to a greater degree. The jolt that is delivered in the narration of Ida's violent death lies not in the physical destruction depicted, but in the force of irony and fragmentation directed at the reader: “Thanks to such timely consideration, we can dispense entirely with Furies. We can follow, step by step, what Franz did and what Ida suffered. There is no unknown quantity in the equation.” ${ }^{88}$ Science brusquely shoves the genres of sympathy, myth, and tragedy aside. In the scene of Mieze's brutal murder the charge of her death cuts to a different tone in the description of the slaughtered calf, in which Mieze's story yields to administrative recipes for the killing of animals. This cannot be entirely attributable to a reference to the unspeakable and thus recuperable to the story of the characters.

What is the source for this Fraktur and why does this matter? One can point to many candidates, including new media such as film and radio, architecture, and of course montage and the city itself. Music stands out, and this is crucial for two reasons. First, the 
novel uses pain and violence as musical phrases so that the reader can construct patterns of listening. ${ }^{89}$ At issue is not meaning but the particular relations between musical ciphers. This explains Döblin’s frequently stated similarity of music and prose, calling “word-art a temporal art like music,” one that shares key rules of "rhythmic structuring, repetition, summations of equinumerous movements."90 Second, Berlin Alexanderplatz draws on music for its experience of an emerging present, wherein the modern epic can resemble symphonic works in which “succession of movements” creates the work's developing impact. ${ }^{91}$ The time of epic narration has its pendant in musical time: "Themes develop musically not just by themselves elsewhere, but rather truly in time, they emerge precisely now."92 They emerge now, I contend, because they result from our reading as the reception of a telling. The action centers on the pragmatic scene, in which both speaker and addressee are being narrated. For this reason, the musicality draws not so much on modern technologies of radio and film but on the ancient technology of the body as a chamber of sounds and sensations. ${ }^{93}$ Regarding musical Fraktur, the connections between the novel's parts are not primarily objects of our perception, but rather the results of perception. ${ }^{94}$ That is, for this violence to exist, one that embeds itself in musical structure, it needs a reader-listener, which returns us to the concern of perception. Fraktur reflects on its own production as a result of reading and hearing.

As we have seen, Jünger presents violence as an autonomous natural phenomenon independent of text or reader. Brecht, while stressing the constructivist nature of violence, wishes to exercise analytical skills; yet the workout trains the emotional body as much as the mind, which rejects the economy of violence. Brecht's reader either practices representations of violence or generates sympathy. By contrast, the reader's empathy in 
Berlin Alexanderplatz is not with the characters but with the book's materiality that collapses meaning and form, book and reader, which I have tried to capture with the term Fraktur..$^{95}$ The novel turns the story of Franz Biberkopf into an event in which the distinction between narrated plot and the narrated reader disintegrates.

It remains an open question whether narrative must be perceived according to natural structures. To argue that narrative is categorized according to natural schemata is not far from arguing that readers' reception of violence is structured in the same way that it would be were it a question of perceiving real violence. The conjectures regarding consciousness in cognitive poetics depend on either biology or inherent functions of language according to cognitive linguistics, perfectly legitimate bases for investigating art. ${ }^{96}$ Yet the rooting of aesthetic reception in biology demands an explanatory model strong enough to account for the presence of fiction at the all stages of art, not merely as at the stages of drive or imitation. At stake too is the status of the decidability between narrated story and narrated reader. For what is experienced is not merely a world of possibly real representations. Experienced also is the impact of the observer and how reading becomes a part of the represented.

What has been forgotten or insufficiently received is Berlin Alexanderplatz's insight: by inserting herself into the gaps of narrative the reader becomes part of the scene. This is also to say that reading in this novel is always accompanied by a second order of reflection, one that observes (naturally?) the unnaturality of its observations. The reader becomes a witness and enters into narration only when she attempts to tell a story about the impact of what she reads. 
In the case of such a prose-work as Berlin Alexanderplatz, in which, in Benjamin's words, “The waves of incident and reflection ... sweep over the reader and destabilize his comfort to this degree,"97 an animating embodied consciousness must disconnect and integrate textual elements. A central feature of Berlin Alexanderplatz is its contingency, the sense that its particles could be different than how they presently appear. Sampling possible connections that readers are likely to anticipate (which anticipation we can explain by way of cognition or convention), the novel marks them as previewed or "typical" without completing the connection. Able to fold violence into a plot only with intensely active engagement, readers must trace violence to fill in the gaps, just as they trace the novel's particular genetic construction. As a result, their own efforts at presenting violence in the act of perceiving — that is, the production of communicationare reintroduced into the object of reading.

Plot is the soul of tragedy, wrote Aristotle; likewise, story is the bread and butter of reading. Both are insufficient for grasping Berlin Alexanderplatz. By complicating story with volatile events of reading, the novel focuses the reader-listener at once on the terrain of the metropolis as mediated and at the same time on the act of reading as an affine phenomenon. Diffused into an active, searching perception, the violent plot is indeed locatable but only on the basis of violence as plot. For Berlin Alexanderplatz does indeed "report the story of Franz Biberkopf," as the novel's first line has it—if by report we mean that Franz is narrated in the way that readers are narrated (both as narrated addressees and constructing narrators). To "listen to this, and to meditate on" this narration is to narrate our own violence. ${ }^{98}$ In this way, at least, readers of the novel 
resemble its protagonist: they, “like Franz Biberkopf, live in a human skin, and, like this

\section{Franz Biberkopf, ask more of life than a piece of bread and butter.”}

I would like to thank the Deutsches Literaturarchiv Marbach for its generous financial support in the form of a Marbacher Stipendium, which made research for this publication possible. I also thank Necia Chronister for her helpful suggestions.

${ }^{1}$ See for instance Jana Howlett and Rod Mengham, The Violent Muse: Violence and the Artistic Imagination in Europe, 1910-1939 (Manchester: Manchester University Press, 1994); Jeffrey H. Goldstein, Why We Watch: The Attractions of Violent Entertainment (New York: Oxford University Press, 1998); Kate Lawson and Lynn Shakinovsky, The Marked Body: Domestic Violence in Mid-NineteenthCentury Literature (Albany: State University of New York Press, 2002); Ian Haywood, Bloody Romanticism: Spectacular Violence and the Politics of Representation, 1776-1832 (Basingstoke: Palgrave Macmillan, 2006); and Elana Gomel, Bloodscripts: Writing the Violent Subject (Columbus: Ohio State University Press, 2003). Gomel investigates predominate typologies of violent subjectivity "to analyze how violence interacts with narrative to generate identity" (xiii).

${ }^{2}$ Violence has also long been the subject of political, juridical, and mythico-religious interpretations. In this context, works by Walter Benjamin, Hannah Arendt, Georges Sorel, and Carl Schmitt are central. See David Pan, “Against Biopolitics: Walter Benjamin, Carl Schmitt, and Giorgio Agamben on Political Sovereignty and Symbolic Order,” German Quarterly 82.1 (2009): 42-62. On symptomatic interpretation, see H P. Abbott, The Cambridge Introduction to Narrative (Cambridge, U.K.: Cambridge University Press, 2002), 104-110; and John Storey, Cultural Studies and the Study of Popular Culture (Athens: University of Georgia Press, 2003), 37-41.

${ }^{3}$ Abel, Marco. Violent Affect: Literature, Cinema, and Critique After Representation (Lincoln: University of Nebraska Press, 2007), $x$.

${ }^{4}$ Peter Imbusch, "The Concept of Violence," in International Handbook of Violence Research, ed. Wilhelm Heitmeyer and John Hagan (Dordrecht: Kluwer Academic Publishers, 2003), 13. An overview of the etymology and origins for the concept of violence is included (15-19). See also John Fraser, Violence in the Arts (London: Cambridge University Press, 1974): "There is in fact no one thing, no chemically insolatable and analyzable substance, that is violence, any more than there is one thing that is sex, even though it is easy to slip into talking as it there were" (9).

${ }^{5}$ Michael Kowalewski, Deadly Musings: Violence and Verbal Form in American Fiction (Princeton: Princeton University Press, 1993), 6. For a range of formalist readings, see Rolf Grimminger, ed., KunstMacht-Gewalt: der ästhetische Ort der Aggressivität (München: W. Fink, 2000).

${ }^{6}$ In this sense the Deleuzian shares features with a traumatic-based approach, which assumes an infinite horizon from which no phenomenon can be observed because it is not complete. On violence, reality, and trauma in literature, see Derek Hillard, "Shadows, Scars, and the Unwritten Pages: Paul Celan and the Reality of Violence,” Colloquia Germanica: Internationale Zeitschrift für Germanistik 37, 3-4 (2004): 26789.

${ }^{7}$ Karl Heinz Bohrer, "Stil ist frappierend. Über Gewalt als ästhetisches Verfahren” in Kunst-Macht-Gewalt, 25.

${ }^{8}$ Ibid., 26.

${ }^{9}$ Hans Ulrich Gumbrecht, “Céline und die Frage, ob Prosa gewaltsam sein kann,” in Kunst-Macht-Gewalt, 133. Grumbrecht's examples of text features mimetically simulate physical acts such as asthma or sexual intercourse.

${ }^{10}$ The field is alternatively referred to as cognitive poetics, cognitive cultural studies, or cognitive literary studies. For a use of brain science to construct a model of filmic aesthetic experience, see Grodal K. Torben, Embodied Visions: Evolution, Emotion, Culture, and Film (Oxford: Oxford University Press, 2009). For a handbook style introduction to the field of cognitive sciences and literature, see Peter Stockwell, Cognitive Poetics An Introduction (Routledge, 2002). For a wide-ranging introduction, see Lisa Zunshine, Introduction to Cognitive Cultural Studies (Baltimore: Johns Hopkins University Press, 2010). For literature and the biocultural, see Nancy Easterlin, A Biocultural Approach to Literary Theory and 
Interpretation. Baltimore: Johns Hopkins University Press, 2012). See also David Herman, Narrative Theory and the Cognitive Sciences (Stanford: CSLI, 2003); Guy Cook, Discourse and Literature: The Interplay of Form and Mind (Oxford: Oxford University Press, 1994); Frederick L. Aldama, Toward a Cognitive Theory of Narrative Acts (Austin: University of Texas Press, 2010); Richardson, Alan. The Neural Sublime: Cognitive Theories and Romantic Texts (Baltimore: Johns Hopkins University Press, 2010); Paula Leverage, Howard Mancing, Richard Schweickert, and Jennifer Marston William. ed., Theory of Mind and Literature (West Lafayette: Purdue University Press, 2011); and Michael Burke, Literary Reading, Cognition and Emotion: An Exploration of the Oceanic Mind (New York: Routledge, 2011). ${ }^{11}$ See for instance Cook, Discourse and Literature, for a discussion of Robert Alain de Beaugrande's views, influential for schema theories, according to which literary works rely on the given understandings about reality "in the sense that, in order to understand both imitation of principles of reality and their violations, we need some kind of reference to the characteristics of reality, to what is familiar to us" (132). While perhaps appearing commonsensical, such a view assumes that primary references are to the real ("what is familiar to us") as something distinct from fiction or imagination. The question whether primary references may be to the fictional ("what is familiar to us") goes unasked.

${ }^{12}$ Monika Fludernik, Towards a 'Natural' Narratology (London: Routledge, 1996), 9. Among her many stated aims is the redefinition of "narrative on the basis of consciousness" instead of plot (27).

${ }^{13}$ Ibid., 34.

${ }^{14}$ See Burke, Literary Reading, 5-13.

${ }^{15}$ Unless this be in terms of the prototypical (and here we are speaking of what is traditionally understood as theme or topos). On prototype, see Patrick Colm Hogan, "The Epilogue of Suffering: Heroism, Empathy, Ethics," SubStance, 30, 1-2: (119-143). For a contrasting view, see Raymond W. Gibbs, "Prototypes in Dynamic Meaning Construal" in Cognitive Poetics In Practice, ed. Joanna Gavins and Gerard Steen (London: Routledge, 2003), 27-40.

${ }^{16}$ May one investigate violence without offering the defensive assurance that the author does not, in the words of Kowalewski, Deadly Musings: "find scenes of violence 'self-referential,' with no subject but their own language” (6)?

${ }^{17}$ This recognizes that experiential and hermeneutic dimensions interact. On the distinction of presencebased and meaning-based culture, see Hans U. Gumbrecht, Production of Presence: What Meaning Cannot Convey (Stanford: Stanford University Press, 2004), 79-87.

${ }^{18}$ On violence and speech in Ernst Jünger's oeuvre, see Guido Graf, "Die Gewalt der Geschwindigkeit: Rhetorische Strategien bei Benjamin, Benn, Döblin und Jünger,” Zeitschrift für Germanistik 1 (1999): 2942. For a discussion of the place of violence in Jünger's politics, see Hugh Ridley, "Irrationalism, Art and Violence: Ernst Jünger and Gottfried Benn,” Weimar Germany: Writers and Politics, ed. Alan F. Bance (Edinburgh: Scottish Academic Press, 1982), 26-37. For as discussion of Jünger's works in terms of the warrior-myth of modernity, see Peter Koslowski, Der Mythos Der Moderne: Die Dichterische Philosophie Ernst Jüngers (München: Fink, 1991). For a psychoanalytic reading of the aesthetics of violence in Wäldchen 125, see Wolfgang Kaempfer, Ernst Jünger (Stuttgart: Metzler, 1981), 63-64. For an analysis of Jünger's revisions to Wäldchen 125, see John King, “Wann hat dieser Scheißkrieg ein Ende?” Writing and Rewriting the First World War (Schnellroda: Antaios, 2003), 262-66.

${ }^{19}$ Ernst Jünger, Wäldchen 125: Eine Chronik aus den Grabenkämpfen 1918 (Berlin: E.S. Mittler \& Sohn, 1930), 162. Citations from this work are cited in the notes with the abbreviation $W$ and page number.

Translations from Jünger are mine. Titled a "chronicle," the narrative draws on Jünger's diaries. For a discussion of the literary chronicle, see Derek Hillard, "Rilke and Historical Discourse Or the 'Histories' of Malte Laurids Brigge,” German Studies Review 29.2 (2006): 299-313.

${ }^{20} W 186$. For a discussion of the break with his early work that Der Arbeiter inaugurates, see Thomas Weitin, Notwendige Gewalt: die Moderne Ernst Jüngers und Heiner Müllers (Freiburg im Breisgau: Rombach, 2003), 146-47.

${ }^{21} W 141$.

${ }^{22} W 142$.

${ }^{23}$ For a recent contribution to this debate, one which interprets the Jünger of the Arbeiter period, see David Pan, "Sacrifice as Political Representation in Bertolt Brecht's Lehrstücke,” The Germanic Review 84.3 (2009): 222-251. Pan argues that Jünger's Gestalt of the later period "never can form the basis of a community with a specific tradition” (236). 
${ }^{24}$ Ernst Jünger, Feuer und Blut: Ein kleiner Ausschnitt aus einer grossen Schlacht (Magdeburg: StahlhelmVerlag, 1925), 72.

${ }^{25}$ Ernst Jünger, “Der Kampf als inneres Erlebnis,” in Sämtliche Werke (Stuttgart: Klett-Cotta, 1980), 7:87.

${ }^{26}$ Ibid., 40.

${ }^{27}$ Ernst Jünger, Blätter und Steine (Hamburg: Hanseatische Verlagsanstalt, 1934) 88. See similar comments in Jünger, Wäldchen, 43.

${ }^{28} W 141$.

${ }^{29} W 173$.

${ }^{30} \mathrm{~W} 173$.

${ }^{31}$ See Ernst Jünger, “On Pain” (New York: Telos Press, 2008).

${ }^{32}$ Weitin, Notwendige Gewalt, 31.

${ }^{33} \mathrm{~W} 1$.

${ }^{34}$ Andreas Huyssen, Twilight Memories: Marking Time in a Culture of Amnesia (London: Routledge, 1995), 135.

${ }^{35}$ See Thomas Gann, “Angst. Zu Transformationen einer Emotion in Ernst Jünger’s In Stahlgewittern und seinen originalen Kriegstagebüchern 1914-1918," Jahrbuch der deutschen Schillergesellschaft December (2010): 422.

${ }^{36}$ Jünger, Feuer und Blut, 81.

${ }^{37}$ Jünger is perhaps building on the privileged relationship between heart and emotion theorized in psychology around 1900, for instance in Wilhelm Max Wundt, Lectures on Human and Animal

Psychology, trans. J.E. Creighton and E.B. Titchener (London: S. Sonnenschein, 1907): "There is really good reason for this relation of the heart's activity to the state of feeling; for the cardiac nerves are those most easily excited by changes in our affective condition. Every affective excitation manifests itself in a weaker or stronger, quicker or slower, heart-beat. Joy and hope make the pulse quick and strong; care and anxiety render it weak and slow; terror arrests it altogether" (370).

${ }^{38}$ See Fludernik, Towards a 'Natural' Narratology: "The reader indirectly participates in the fictional process and recuperates or re-cognizes characters' experientiality in a vicarious manner” (374).

${ }^{39}$ W 209.

${ }^{40}$ On Hegel, see Rolf-Peter Horstmann, Wahrheit Aus Dem Begriff: Eine Einführung in Hegel (Frankfurt am Main: Anton Hain, 1990).

${ }^{41}$ See Russell A. Berman, "Preface” in Jünger, "On Pain,” where he notes the "conventional political thinking [that] still tries to police a neat separation between left and right" (viii). For a 1980s challenge to this “neat separation,” see Helmut Lethen, “Ernst Jünger, Bertolt Brecht und der 'Habitus' des

Einverständnisses mit der Modernisierung,” Studi Germanici 21-22, 59-64 (1983): 273-89.

${ }^{42}$ For a treatment of sacrifice as a public event, see Pan, "Against Biopolitics,” 236. I would add that violence is not just required to preserve community, as Pan argues, but also to make it come into being in the first place.

${ }^{43}$ Bertolt Brecht, The Measures Taken and Other Lehrstücke, trans. John Willett and Ralph Manheim (New York: Arcade Publishing, 2001), 85. Citations from this work are cited in the notes with the abbreviation $M$ and page number.

${ }^{44}$ For Brecht's comments, see Reiner Steinweg. Das Lehrstück. Brechts Theorie einer ästhetischen

Erziehung (Stuttgart: Metzler, 1972), 61.

${ }^{45} \mathrm{M} 9$.

${ }^{46}$ On the Lehrstück, see Roswitha Mueller, "Learning for a New Society: The Lehrstück,” in The Cambridge Companion to Brecht, ed. Peter Thomson and Glendyr Sacks (Cambridge: Cambridge University Press, 2006), 79-103.

${ }^{47} M 32$.

${ }^{48} M 32$.

${ }^{49} M 34$.

${ }^{50}$ For a contribution to the debate on cognitive versus emotional response, see Alex Neill, "Art and Emotion" in The Oxford Handbook of Aesthetics, ed. Jerrold Levinson (Oxford: University Press, 2003), 425-27.

${ }^{51}$ See Antony Tatlow, Mask of Evil: Brecht's Response to the Poetry, Theatre and Thought of China and Japan (Bern: Peter Lang, 1977), 197-201. On the methodology of measuring emotional responses, see Keen, Suzanne, Empathy and the Novel (Oxford: Oxford University Press, 2007): "Discussion of fiction 
that takes place in public settings, while extremely valuable in itself, may not be the most unreliable source of evidence for emotional responses to fiction" (78). Yet the fact that the viewers' responses noted by Tatlow were against the grain of the authoritative interpretation lends credence to their reactions.

${ }^{52} M 33$.

${ }^{53}$ See William Rasch, “Theories of the Partisan: Die Maßnahme and the Politics of Revolution.” Brecht Yearbook/Das Brecht-Jahrbuch 24 (1999): 330-43.

${ }^{54}$ For Brecht's comments on the need to alter the play, see Steinweg, Die Maßnahme, 238.

${ }^{55}$ For a discussion of empathy, see Antonio Damasio, Looking for Spinoza: Joy, Sorrow, and the Feeling Brain (Orlando: Harcourt, 2003).

${ }^{56}$ See Bernhard Waldenfels, “Aporien der Gewalt," in Gewalt: Strukturen, Formen, Repräsentationen , ed. Mihran Dabag and Bernhard Waldenfels (München: W. Fink, 2000 ), 11.

${ }^{57}$ For readings in terms of gender, see Maria Tatar, “'Wie süß ist es, sich zu opfern’ Gender, Violence, and Agency in Döblin's Berlin Alexanderplatz,” Deutsche Vierteljahrsschrift fur Literaturwissenschaft und Geistesgeschichte 66.3 (1992): 491-518; Hania Siebenpfeiffer, "Böse Lust": Gewaltverbrechen in Diskursen der Weimarer Republik (Köln/Weimar/Wien: Böhlau 2005); Karsten Uhl, “Die Gewaltverbrecherin im kriminologischen und literarischen Diskurs des frühen 20. Jahrhunderts," in Frauen und Gewalt. Interdisziplinäre Untersuchungen zu geschlechtsgebundener Gewalt in Theorie und Praxis, ed. Antje Hilbig, Claudia Kajatin and Ingrid Miethe (Würzburg: Königshausen \& Neumann, 2003), 91-103. On sacrifice, see Hans-Peter Bayerdörfer, "Der Wissende und die Gewalt: Alfred Döblins Theorie des epischen Werkes und der Schluß von Berlin Alexanderplatz," Deutsche Vierteljahrsschrift Literaturwissenschaft und Geistesgeschichte 44 (1970): 318-53; Wolfgang Düsing, Erinnerung und Identität: Untersuchungen zu einem bei Musil, Döblin und Doderer Erzählproblem (München: Fink, 1982), 128; Timothy Casey, "Alttestamentliche Motive in Döblins Berlin Alexanderplatz: Die Rezeption des Romans und der Streit um sein Schlussbild," in Paradeigmata: Literarische Typologie des alten Testaments, II: 20. Jahrhundert, ed. Franz Link (Berlin: Duncker \& Humblot, 1989), 527-543. For discussion of the novel and trauma, see Alexander Honold, "Der Krieg und die Großstadt: Berlin Alexanderplatz und ein Trauma der Moderne," in Alfred Döblin und die künstlerische Avantgarde in Berlin, ed. Hartmut Eggert and Gabriele Prauß (Bern: Peter Lang, 2003), 191-211. See also Michael Baum, Kontingenz und Gewalt: Semiotische Strukturen und erzählte Welt in Alfred Döblins Roman 'Berlin Alexanderplatz’ (Würzburg: Königshausen \& Neumann, 2003). In Baum's semiotic analysis, violence is collocative of contingency, whereby violence is an answer to a necessary contingency of meaning (225).

${ }^{58}$ See Baum, Kontingenz und Gewalt, 213-15. For discussion of how Biberkopf's "anger can climax in outbursts of violence," see Peter Jelavich, Berlin Alexanderplatz: Radio, Film, and the Death of Weimar Culture (Berkeley: University of California Press, 2006), 29.

${ }^{59}$ Waldenfels, “Aporien der Gewalt," 17.

${ }^{60}$ As opposed to its autonomy in Berlin Alexanderplatz, violence in terms of causality, representation, and explanation wears the face of the humanist, pre-revolutionary, and bourgeois individual. Writers of the decade of neue Sachlichkeit (1920-1930) shared an antagonism to the placement of the bourgeois subject at the center. Violence conceived in terms of the bourgeois individual stresses sociological, economic, or psychological factors. For Berlin Alexanderplatz these are of mere scenic consequence.

${ }^{61}$ Waldenfels, “Aporien der Gewalt,” 16.

${ }^{62}$ For a discussion of use and waste in Anglo-American modernist violence, especially T.S. Eliot, see Sarah Cole, "Enchantment, Disenchantment, War, Literature," Publications of the Modern Language Association of America 124.5 (2009): 1632-1947.

${ }^{63}$ Alfred Döblin, Berlin Alexanderplatz: The Story of Franz Biberkopf, trans. Eugène Jolas (London: Continuum, 2004), 2. Citations from this work are cited in the notes with the abbreviation $B A$ and page number. Translations of other texts by Döblin are mine.

${ }^{64}$ For this notion, see Helmut Lethen, Verhaltenslehren der Kälte: Zwischen den Kriegen (Frankfurt am

Main: Suhrkamp, 1994), 169.

${ }^{65}$ Tatar, “Wie süß ist es, sich zu opfern,” 501.

${ }^{66}$ BA 288.

${ }^{67}$ Alfred Döblin, Das Ich über der Natur (Berlin: Fischer, 1928), 34.

${ }^{68}$ BA 599.

${ }^{69}$ BA 616. 
${ }^{70}$ (For a discussion of how Buch replaces the traditional nature-opposite with Berlin's urban space, see Klaus R. Scherpe, “The City as Narrator: The Modern Text in Alfred Döblin's Berlin Alexanderplatz,” in Modernity and the Text: Revisions of German Modernism, ed. Andreas Huyssen and David Bathrick (New York: Columbia University Press, 1989), 167.

${ }_{72}^{71}$ Arnold van Gennep, The Rites of Passage (Chicago: University of Chicago Press, 1968), 81.

${ }^{72}$ BA 583.

${ }^{73} B A 584$.

${ }^{74}$ BA 598 .

${ }^{75}$ Döblin, Das Ich über der Natur, 42. This might call to mind Jünger's notion of nature's violence inherent in the human. Yet Döblin here writes not of a biological urge but of a force standing behind nature and manifesting itself not primarily in human violence but in phenomenological manifestation itself.

${ }^{76}$ Ibid., 43.

${ }^{77}$ Alfred Döblin, Aufsätze zur Literatur, ed. Walter Muschg (Olten: Walter-Verlag, 1963), 66.

${ }^{78}$ Ibid.

${ }^{79}$ Walter Benjamin, Selected Writings, ed. Marcus Bullock and Michael W. Jennings, vol II:1 (Cambridge, MA and London: Belknap Press, 1999), 303 (the other event is Mieze's murder).

${ }^{80}$ Etymologisches Wörterbuch des Deutschen, $5^{\text {th }}$ ed., s.v. “Arm.”

${ }^{81}$ Benjamin, Selected Works. II:1, 301.

${ }^{82}$ Kluge, Friedrich. Etymologisches Wörterbuch der Deutschen Sprache, ed. Elmar Seebold (Berlin: De Gruyter, 2002).

${ }^{83}$ Alfred Döblin, Berlin Alexanderplatz: Die Geschichte vom Franz Biberkopf, ed. Werner Stauffacher (München: Deutscher Taschenbuch Verlag, 2001), 411 (“Sie redet Fraktur mit ihm," my translation).

${ }^{84}$ BA 218.

${ }^{85}$ Benjamin, Selected Works. II:1, 302.

${ }^{86}$ On the famous imprint of Döblin's hand, see Devin Fore, “Döblin’s Epic: Sense, Document, and the Verbal World Picture.” New German Critique 99 (2006): 193-94.

${ }^{87}$ BA 499.

${ }^{88}$ BA $124-125$.

${ }^{89}$ Döblin's writings on the centrality of music emerge at the same time as his literary texts. See Alfred Döblin. Schriften zu Ästhetik, Poetik und Literatur (Olten: Walter-Verlag, 1989), 613.

${ }^{90}$ Alfred Döblin, Kleine Schriften, ed. Anthony W. Riley and Walter Muschg, vol 1 Kleine Schriften: 1 (Olten: Walter-Verlag, 1985), 269. Here is where repetition as mimesis is of concern for the novel-the mimesis of musicality—familiar from Nietzsche's Geburt der Tragödie and the expressionists, both significant points of reference for Döblin.

${ }^{91}$ Döblin, Aufsätze zur Literatur, 129.

${ }^{92}$ Ibid., 123.

${ }^{93}$ See Benjamin, Selected Writings. II:1: "Biblical verses, statistics, and texts from hit songs ... correspond to the formulaic forms of the traditional epic" (301).

${ }^{94}$ For the inspiration of this critical stance, see Peter Szondi, Celan Studies, trans. Susan Bernofsky with Harvey Mendelsohn (Minneapolis: University of Minnesota Press, 2003), 29.

${ }^{95}$ Benjamin makes a similar remark about film: "The audience's empathy with the actor is really an empathy with the camera” (260). This is not merely to say that Döblin succeeds in blocking identification where Brecht fails. On empathy, it is significant that Döblin removed from the published form an epic and explicit invitation for the reader to empathize with Franz. See Döblin, Berlin Alexanderplatz: Die Geschichte vom Franz Biberkopf (Zürich: Walter, 1996): "We will sympathize in everything, and I will not leave you, taking my feelings with me, so that you don't stand before things unfeelingly" (823).

${ }^{96}$ See Stockwell, 135-36.

${ }^{97}$ Benjamin, Selected Works. II:1, 301.

${ }^{98}$ BA 2. 